\title{
НОВЫЕ НАПРАВЛЕНИЯ РАЗВИТИЯ МЕСТНОГО САМОУПРАВЛЕНИЯ: ИНТЕГРИРОВАНИЕ РЕГИОНАЛЬНОЙ, ФЕДЕРАЛЬНОЙ И МЕСТНОЙ ВЛАСТИ
}

\section{NEW DIRECTIONS OF LOCAL SELF-GOVERNMENT DEVELOPMENT: INTEGRATION OF REGIONAL, FEDERAL AND LOCAL AUTHORITIES}

\section{Kuliyev Rauf Alim oglu}

Summary. New directions of development of local self-government are investigated.

In particular, the issues of optimization and sustainability of municipal budgets as the basis for the financial self-sufficiency of local selfgovernment bodies, the state of local self-government budgets, which becomes a priority task in the context of the sovereignty of local selfgovernment, are briefly considered.

It is shown that at the level of local self-government, a vital problem is the creation of the necessary conditions for the population to independently solve local issues, which will expand the economic base of municipalities that focus on the horizons of their development, including through the implementation of national projects such as "Education", "Culture”, “Health", “Demography”, “Ecology”, "Housing and Urban Environment", "Digital Economy", etc.

The article analyzes the practical possibility of forming the institution of a digital municipality, the implementation of the powers of local self-government bodies to activate the practice of using digital technologies.

It is noted that the public authorities will continue to ensure the vital activity of the population of municipalities, directing their efforts to the socio-economic development of the territories under their jurisdiction.

It is concluded that the municipal economy as the economic quintessence of local self-government will take an adequate position in the overall structure of the national economy, and municipal relations will form a stable municipal process that promotes high-quality structural development, while the creation of a digital municipality will improve the quality, for example, of systematized subject-specific accounting of property on the balance sheet of municipalities, municipal transport infrastructure, which will fill local budgets.

Keywords: municipal farms, management theory, municipal process, local self-government, civil society, municipalities, national projects.
Кулиев Рауф Алим оглы

Преподаватель, АНО «Институт деловой карьеры», Москва

kr_gabi@mail.ru

Аннотация. Исследованы новые направления развития местного самоуправления.

В частности, кратко рассмотрены вопросы оптимизации и устойчивости муниципальных бюджетов в качестве основы финансовой самодостаточности органов местного самоуправления, состояния бюджетов местного самоуправления, что становится задачей первостепенной важности в контексте суверенности местного самоуправления.

Показано, что на уровне местного самоуправления жизненно важной проблемой выступает создание необходимых условий для самостоятельного решения населением вопросов местного значения, что расширит экономическую базу муниципалитетов, ориентирующихся на горизонты своего развития, в том числе через реализацию национальных проектов, таких как «0бразование», «Культура», «Здравоохранение», «Демография», «Экология», «Жильё и городская среда», «Цифровая экономика» и др.

Анализируется практическая возможность формирования института цифрового муниципалитета, реализации полномочий органов местного самоуправления по активизации практики использования цифровых технологий.

Сделан вывод, что муниципальное хозяйство как экономическая квинтэссенция местного самоуправления займёт адекватную ему позицию в общей структуре народного хозяйства, а муниципальные отношения сформируют устойчивый муниципальный процесс, содействующий качественному структурному развитию, при том, что создание цифрового муниципалитета повысит качество, к примеру, систематизированного попредметного учёта собственности, находящейся на балансе муниципалитетов, муниципальной транспортной инфраструктуры, что наполнит местные бюджеты.

Ключевые слова: муниципальные хозяйства, теория управления, муниципальный процесс, местное самоуправление, гражданское общество, муниципалитеты, национальные проекты. 
$\Pi$ оправки к Конституции Российской Федерации, предложенные Президентом РФ в январе 2020 года, были приняты Законом в марте 2020 года [1]. Поправками, относящимися к организации местного самоуправления, декларируется единство государственной и местной власти, чем создаётся новая система единой публичной власти.

Вместе с тем, ретроспективный обзор показывает, что конституционная муниципальная концепция опирается на ранее действующее законодательство. В этой связи следует отметить, что в истории местного самоуправления начало советского периода ознаменовалось, прежде всего, национализацией земских средств и ресурсов [2] и вплоть до смены руководства в стране в 1953 г., роль советов как органа местного самоуправления постоянно ослабевала, при том, что государственная власть стала пронизывать всю территориально - хозяйственную организацию.

С принятием постановления «Об улучшении деятельности Советов депутатов трудящихся и усилении их связи с массами» от 22 января 1957 года [3] ставились задачи по децентрализации и демократизации государственного управления, усиления роли Советов [4].

Анализ показывает, что предпринятые попытки усилить роль органов местного самоуправления не смогли по понятным причинам расширить, ни демократизацию, ни хозяйственные возможности самоуправления, хотя, неоспоримо - деятельность местных советов оживилась, внедрялись новые формы в их практическую работу.

В семидесятые годы прошлого века усилилась централизация, что привело к некоторому забвению местного самоуправления, и вновь интерес к нему проявился в период подготовки проекта Конституции страны (1977 г.), с принятием которой советы стали именоваться «Советами народных депутатов» [5].

Следующая трансформация - поиск путей преодоления номинального проявления местной власти, сужения её подчиненного, а точнее, что было злободневно - декоративного содержания, развивалась на этапе новейшей истории: с августа 1991 г. муниципальное развитие прошло довольно извилистый и неоднозначный путь, анализ которого необходим для понимания состояния муниципальной среды в более отдалённой перспективе.

Исторический опыт показывает, что с одной стороны, Конституция РФ 1993 г. завершила историю советов народных депутатов [6], а с другой, после принятия за- кона «Об общих принципах организации местного самоуправления в Российской Федерации» [7] функции государственной власти на местах были переданы избираемым органам местного самоуправления как новому демократическому институту управления.

Безусловно, узкие места, которые важно было преодолеть, к примеру, слабый уровень компетенций муниципальных образований, низкое взаимодействие госвласти и органов местного самоуправления, скудная ресурсная база для выполнения ими своих обязанностей и пр. привели к принятию в 2003 г. нового закона «Об общих принципах организации местного самоуправления в Российской Федерации» [8].

Уже в тот период видны были противоречия, заложенные в законе: так, экономические и правовые механизмы, которые регулируют развитие муниципальных отношений, а кроме того, управленческие функции органов местного самоуправления разрабатывались в центре, тогда как осуществление задач и функций муниципального уровня, то эти управленческие задачи реализовывались на местах, где исходя из местных условий и особенностей складываются специфические отношения, которые не всегда понятны и видны сверху.

Унифицирование организации местного самоуправления согласно ст. 131-Ф3 не дала преимуществ в принятии эффективных управленческих решений по вопросам социально-экономического развития, поскольку муниципальные отношения, их содержание, структура и функции зависели от полномочий, спускаемых сверху, что сжимало многие муниципальные полномочия, вероятность реализации необходимых населению услуг.

Т.о., в законодательство, регулирующее деятельность органов местного самоуправления, периодически вносились изменения. Внесены они были и в январе 2020 года в рамках современного экономического формата как принципиальные возможности государства влиять на муниципальный процесс на Совете, обсудившем «ключевые задачи и перспективы развития местного самоуправления» [9], что, по существу, положило начало муниципальной реформе, уже стоящей на повестке дня.

Новые публичные полномочия и функции, предложенные в деятельности органов местного самоуправления, базируются на следующих практических задачах: задачах по наделению местной (муниципальной) власти новыми публичными полномочиями и функциями, что даст возможность без сомнения определять сферу взаимодействия муниципалитетов и государства в их соприкосновении, и такой сферой является вы- 
полнение ими важных государственных полномочий и функций, что обусловлено, с одной стороны, их социальным предназначением, а, с другой - публично властной природой. При том, поле взаимодействия местного самоуправления и государственной власти весьма обширно и включает работу по реализации государственных задач, охватывающих комплекс вопросов, сочленённых с участием наряду с муниципальными органами государственных органов власти по проведению государственной политики в социальной сфере, в области образования, здравоохранения, культуры, экологии и пр. И идеологи реформы это взаимодействие местного самоуправления и государственной власти определили необходимостью решения задач с наибольшей отдачей в интересах населения, проживающего на соответствующих территориях, необходимостью эффективной реализации полномочий.

Становится важным, что взаимодействие органов местного самоуправления и государственной власти до внесения в Конституцию РФ части 3 ст. 132 дополнилось следующим содержанием: «Органы местного самоуправления и органы государственной власти входят в единую систему публичной власти в Российской Федерации» строится на исполнении муниципалитетами отдельных полномочий, которые реализуются для решения местных вопросов органами местного самоуправления городских округов, муниципальных районов и округов, внутригородских районов поселений [10].

Говоря о единой системе публичной власти, новая редакция Конституции Российской Федерации закрепляет новую категорию - «публичная власть», определены её признаки и понятие. Как мы видим, органы публичной власти, став важнейшей составляющей политической системы, зададут новые направления во взаимодействии органов власти на федеральном, региональном и местном уровнях, продолжат обеспечивать жизнедеятельность населения муниципальных образований, направляя свои усилия на социально-экономическое развитие подведомственных им территорий.

Важным вопросом комплексной деятельности отдельных составляющих муниципальныххозяйств выступает оптимизирование и устойчивость муниципальных бюджетов как основа финансовой самодостаточности органов местного самоуправления. Это, безусловно, определено тем, что состояние бюджетов местного самоуправления, соответствие функций и в целом потенциалу муниципального уровня - «самого близкого к людям с огромной сферой ответственности» [11], становится задачей первостепенной важности в контексте суверенности местного самоуправления. Что, вне всякого сомнения, с одной стороны, сведёт к миниму- му многочисленные источники, затрудняющие работу муниципальных хозяйств, и, возможно, будет преодолена «финансовая несостоятельность муниципалитетов», которая сегодня заложена в самой системе налогообложения [12], муниципалитеты получат, наконец, возможность, во-первых, полновесно оплачивать собственную зону ответственности, расходы муниципалитетов, капитальные расходы, во-вторых, осуществлять инновационно- инвестиционные проекты в целях поступательного развития, и, в-третьих, обладая самодостаточностью и автономностью, смогут на деле использовать производственный, кадровый, социальный и территориальный потенциал, что могло бы послужить критерием закрепления муниципальных владений.

С другой стороны, что немаловажно, муниципальное хозяйство как экономическая квинтэссенция местного самоуправления займёт адекватную ему позицию в общей структуре народного хозяйства, а муниципальные отношения сформируют устойчивый муниципальный процесс, содействующий качественному структурному развитию.

На уровне местного самоуправления жизненно важной проблемой выступает создание необходимых условий для самостоятельного решения населением вопросов местного значения [13].

Создавать необходимые условий для самостоятельного решения населением вопросов местного значения, что расширит экономическую базу муниципалитетов, возможно через реализацию национальных проектов «Образование», «Культура», «Здравоохранение», «Демография», «Экология», «Жильё и городская среда», «Цифровая экономика» и др.

Но муниципалитеты должны ориентироваться на горизонты своего развития. Однако, налицо сокращение соотношения полномочий и возможностей, в частности, у управ районов Москвы, где количество полномочий районных Управ сокращено со 142 до 106 в период с 2010 по 2018 гг., т.е. более чем на четверть [14]. В силу чего столь злободневно озвучена необходимость обновить основы государственной политики, что активизирует стратегию по части местного самоуправления.

Ещё одной практической возможностью реализовать полномочия органов местного самоуправления может стать активизация практики использования цифровых технологий.

Формирование цифровой экономики входит в состав преимущественных целей развития местного самоуправления. В этой совокупности стоит задача сформировать институт цифрового муниципалитета. 
Поэтому в аспекте выстраивания постоянных муниципальных проблем создание цифрового муниципалитета усилит вероятность, к примеру, определения величины интегрирования отдельных разновидностей учёта, проводимого органами местного самоуправления, в общую информационную систему для проведения, например, систематизированного попредметного учёта собственности, находящейся на балансе муниципалитетов, населения, реестров юридических лиц и пр. К тому же использование цифровых технологий ревальвирует муниципальную транспортную инфраструктуру, транспортное и градостроительное планирование, что наполнит местные бюджеты.

Достичь новых условий развития местного самоуправления возможно, предопределив задачи по его развитию, которые, к примеру сказать, могут быть направлены:
- во-первых, на разработку методических рекомендаций по участию органов местного самоуправления в нацпроектах;

- во-вторых, на доработку пространственной стратегии развития России с учётом объективных возможностей интегрирования региональной, федеральной и муниципальной власти;

- в-третьих, на пошаговую передачу на муниципальный уровень отдельных налогов, поступление которых напрямую обусловлено главным образом работой муниципальных образований.

Обобщённо говоря, смогут ли в соответствии с Законом «Об общих принципах организации местного самоуправления» его звенья - муниципальное хозяйство, муниципальная территория, и местное самоуправление реализовать социально-экономический потенциал муниципального уровня - покажет время.

\section{ЛИТЕРАТУРА}

1. Закон Российской Федерации о поправке к Конституции Российской Федерации от 14 марта 2020 г. № 1-Ф3К «0 совершенствовании регулирования отдельных вопросов организации и функционирования публичной власти (ст. 67, ч. 1; п. «г» ст. 71; ч. 2 ст. 80; ст. 132, ч. 3) // Российская газета — Федеральный выпуск № 55 (8109).

2. Собрание узаконений и распоряжений правительства за 1917-1918 гг. Управление делами Совнаркома СССР.— М., 1942.—C. 538.

3. Постановление ЦК КПСС «0б улучшении деятельности Советов депутатов трудящихся и усилении их связи с массами» от 22 января 1957 года // Испол. ком. Сталинского обл. Совета депутатов трудящихся. Организационно-инструкторский отд.-Сталино: [б.и.], 1957.

4. Программа Коммунистической партии Советского Союза.-М., Госполитиздат, 1961. С. 102.

5. Конституция СССР. М., 1977. // Закон СССР от 7 октября 1977 г. № 6367-ІХ «0 порядке введения в действие Конституции (Основного закона) СССР», статьи 146-150.

6. Конституция Российской Федерации.-М., 1993.—- т. 131.

7. Федеральный закон № 154 — Ф3 от 15. 08. 1995 г. «0б общих принципах организации местного самоуправления в Российской Федерации» // — Российская газета.— 1995.— № 12.

8. Федеральный закон № 131 — Ф3 от 06. 10. 2003 г. «06 общих принципах организации местного самоуправления в Российской Федерации» // — Российская газета. - 2003. - № 17.

9. http://www.kremlin.ru/events/president/news/62701

10. Ст. 17 Федерального закона от 06. 10. 2003 г. № 131 - Ф3 (в ред. от 29.12.2020) «06 общих принципах организации местного самоуправления в Российской Федерации» (с изм. и доп., вступ. В силу с 23.03.2021) // consultant.ru

11. http://prezident.org/tekst/stenogramma-zasedanie-soveta-po-razvitiyu-mestnogo-samoupravlenija-30-01-2020.html

12. Зотиков Н.З. Ганцгорн Е.Д. Муниципальные финансы, порядок их формирования // Совершенствование финансово-кредитного механизма регионов. Сб. материалов Всероссийской заочной научно-практической конференции. - 2017. - C. 41-45.

13. Ст. 16 Федерального закона от 06. 10. 2003 г. № 131 — Ф3 (в ред. от 29.12.2020) «06 общих принципах организации местного самоуправления в Российской Федерации» (с изм. и доп., вступ. в силу с 23.03.2021) // consultant.ru

14. Мусинова Н.Н. Тенденции развития местного самоуправления в городе Москве // Вестник университета. — № 4. - 2018. — C. 20.

(с Кулиев Рауф Алим оглы ( kr_gabi@mail.ru).

Журнал «Современная наука: актуальные проблемы теории и практики» 